BULLETIN OF PNRPU. GEOLOGY. OIL \& GAS ENGINEERING \& MINING

ВЕСТНИК ПНИПУ. ГЕОЛОГИЯ. НЕФТЕГАЗОВОЕ И ГОРНОЕ ДЕЛО

ISSN 2224-9923

Volume/ Tom 15 №19 2016

http://vestnik.pstu.ru/geo/

УДК 622.363.2:539.16.04:615.835

Article / Статья

(C) PNRPU / ПНИПУ, 2016

\title{
USE OF SYLVINITE DEDICATED TO VERKHNEKAMSKOE FIELD OF POTASH AND MAGNESIUM TO INCREASE QUALITY AND IONIZATION OF AIR ENVIRONMENT
}

\author{
K.A. Chernyi, G.Z. Fainburg
}

Perm National Research Polytechnic University (29 Komsomolskii av, Perm, 614990, Rissian Federation)

\section{ИСПОЛЬЗОВАНИЕ СИЛЬВИНИТА ВЕРХНЕКАМСКОГО МЕСТОРОЖДЕНИЯ КАЛИЙНО-МАГНИЕВЫХ СОЛЕЙ ДЛЯ ПОВЫШЕНИЯ КАЧЕСТВА ВОЗДУШНОЙ СРЕДЫ И УРОВНЯ ЕЕ ИОНИЗАЦИИ}

\section{К.А. Черный, Г.3. Файнбург}

Пермский национальный исследовательский политехнический университет (614990, Россия, г. Пермь, Комсомольский пр., 29) Received / Получена: 24.02.2016. Асcерted / Принята: 20.04.2016. Published / Опубликована: 30.06.2016

Key words:

sylvinite, potassium chloride, potassium-40, beta radiation, gamma radiation, speleoclimatic chamber, air ionization, air ions, electric mobility, unipolarity factor.

\section{Ключевые слова:}

сильвинит, хлорид калия, калий-40, бета-излучение, гамма-излучение, спелеоклиматическая камера, ионизация воздуха, аэроионы, электрическая подвижность, коэффициент униполярности.
Urbanization of territories and growth of man-made air pollution require creating and widely implementing means, methods and materials to increase air quality of indoor premises through ionization. Increase of air quality of indoor premises is on the front burner which is caused by following reasons of natural air deionization: aerosol and gas pollution and air cleaning from its pollution. Wherein, use of conventional methods of electrostatic generation of air ions is restricted by its side effects.

This paper reviews new prospecting methods to create qualitative and treatment air environment inside premises through its air ionization by interaction of air and natural sylvinite, containing silvite (potassium chloride).

The paper presents generalized experimental data including air ionization of premises for treatment and health-recovering purposes that represent sylvinite speleoclimatic chambers with surfaces of different design made of either sawn sylvinite blocks of natural sylvinite or pressed salt tile with high concentration of potassium chloride etc. Air ionization occurs primarily due to beta radiation of natural radioactive isotope potassium- 40 .

Concentration of air ions of positive and negative polarity and different mobility (light, moderate and heavy air ions) are studied. Spectrum distribution of air ions of light mobility group of negative polarity are analyzed in details. In the range of mobility more than $2 \mathrm{~cm}^{2} \mathrm{~B}^{-1} \mathrm{sec}^{-1}$ unipolarity coefficient is always less than 1 . In the range of $1-2 \mathrm{~cm}^{2} \mathrm{~B}^{-1} \mathrm{sec}^{-1}$ unipolarity $^{-1}$ coefficient is larger than 1.

Obtained results prove high efficiency of application of sylvinite construction materials to create high-quality, treatment or health-recovering air environment, allow to select special construction and decoration materials based on sylvinite depending on required parameters of air ion composition it order to create high-quality air in the premises.

Урбанизация территорий и нарастание техногенного загрязнения воздушной среды все настойчивее требуют создания и широкого внедрения средств, способов и материалов для улучшения качества воздушной среды внутренних помещений, в первую очередь за счет аэроионизации. Актуальность именно этого направления улучшения качества воздуха внутренних помещений связана с двумя основными причинами деионизации природного воздуха: во-первых, вследствие его аэрозольного и газового загрязнения, а во-вторых, в процессе очистки воздуха от этих загрязнений. При этом применение известных классических способов электростатического генерирования аэроионов ограничено их побочными эффектами.

В настоящей работе рассмотрены новые перспективные способы создания качественной, вплоть до лечебной, воздушной среды помещений путем их аэроионизации за счет взаимодействия воздуха с природным сильвинитом, содержащим сильвин (хлорид калия).

Представлены обобщенные экспериментальные данные об аэроионизации воздуха специальных помещений лечебного и оздоровительного назначения - сильвинитовых спелеоклиматических камер с поверхностями разных конструкций, выполненных из пиленых сильвинитовых блоков природного сильвинита; из прессованной соляной плитки с высоким содержанием хлористого калия и др. Аэроионизация возникает в первую очередь за счет бета-излучения природного радиоактивного изотопа калия-40.

Исследованы концентрация аэроионов положительной и отрицательной полярности различной подвижности (легкие, средние промежуточные и тяжелые аэроионы). Детально рассмотрены спектральные распределения аэроионов легкой группы подвижности отрицательной полярности. В диапазоне подвижности более $2 \mathrm{~cm}^{2} \mathrm{~B}^{-1} \mathrm{c}^{-1}$ коэффициент униполярности всегда меньше единицы, в то время как в диапазоне $1-2 \mathrm{~cm}^{2} \mathrm{~B}^{-1} \mathrm{c}^{-1}$ значение коэффициента униполярности всегда больше единицы.

Полученные результаты подтверждают высокую эффективность применения сильвинитовых строительных материалов для создания высококачественной, лечебной или оздоровительной воздушной среды, позволяют оптимально выбирать специальные строительные отделочные и декоративные материалы на основе сильвинита в зависимости от требуемых параметров аэроионного состава с целью формирования качественного воздуха помещений.

Konstantin A. Chernyi - Doctor of Engineering, Associate Professor at the Department of Life Safety (tel.: +007 342 219 81 73, e-mail: chernyy_k@mail.ru). Grigorii Z. Fainburg (Author ID in SCOPUS: 6506555582) - Doctor of Engineering, Professor at the Department of Development of Mineral Deposits (tel.: +007 342 219 8042, e-mail: faynburg@mail.ru).

Черный Константин Анатольевич - доктор технических наук, доцент кафедры безопасности жизнедеятельности (тел.: +007 3422198173 , e-mail: chernyy_k@mail.ru). Контактное лицо для переписки.

Файнбург Григорий Захарович - доктор технических наук, профессор кафедры разработки месторождений полезных ископаемых (тел.: +007 3422198042 , e-mail: faynburg@mail.ru). 


\section{Introduction}

In the conditions when a human spend time in closed premises and experience "air discomfort" it is on the front burner and more important to overcome such challenge than to study other things. Several authors [1-6] point the cause of air discomfort in the premises as a change of air ion concentration in comparison with natural air. There is significant decrease of light ion concentration occurs in the premises. Under the conditions of lack of natural mechanisms to generate light air ions and to absorb it during human breathing, sedimentation on aerosol particles and adsorption by surfaces of its concentration is decreased dramatically.

The way to compensate lack of light air ions through its artificial generation with use of special equipment is restricted due to negative influence of corrosion ionizators. They cause ion inducted chemical reaction and side effect of harmful chemicals such as ozone $\mathrm{O}_{3}$ as well as nitrogen oxides $\mathrm{NO}$, $\mathrm{NO}_{2}, \mathrm{NO}_{x}$ [7-9].

Natural methods to provide required level of air ionization have not mentioned disadvantage [10]. They are base on use of special construction matter or materials of salt rocks that are used for lining or decorating limiting surfaces of premises, floor or calling. Besides, in order to design unique medical microclimate of speleoclimatic chamber [11, 12] of lining [13] and/or construction elements natural sylvinite is used.

It is well known, that there are both low and relatively high shares of radioactive emission. It depends on concentration of chemicals in the rocks of natural (caves) or artificial mining (potassium mining) [14-18]. High emissions are caused by high concentration of light air ions.

At the present time there are no papers that generalize different theoretical and experimental results by the same physical parameter. Studies carried today represent either emission evaluation [19-21] or evaluation of ion concentration [22] without consideration of the factors that cause formation of air ion composition.
Thus, based on physical laws and considered experimental results to highlight main rules of implementation of ion formation, caused by radioactive influence of potassium salts.

\section{Ionization emissions of potassium salts}

The main contribution to ionization in potash mines and in speleoclimatic chambers belongs to ionization of potassium radiation contained in potassium and magnesium salts. Rock minerals containing potassium are sylvite and carnallite; rocks are sylvinite and carnallite. Average composition of sylvinite ore of Verkhnekamskoe field of potassium chloride are as follows: $\mathrm{KCl}-25.5 \%$; $\mathrm{NaCl}-68.5 \% ; \mathrm{MgCl}_{2}-0.8 \% ; \mathrm{CaSO}_{4}-1.9 \%$, insoluble precipitation - 2.7\%; $\mathrm{H}_{2} \mathrm{O}-0.6 \%$ [18].

There are to stable isotopes of potassium such as ${ }^{39} \mathrm{~K}(93.08 \%),{ }^{41} \mathrm{~K}(6.91 \%)$ and radioactive isotope ${ }^{40} \mathrm{~K}(0.0117 \%)$ which is decomposed in two different ways.

First way includes $\beta$-decomposition of ${ }^{40} \mathrm{~K}$ (89.28\%) and its transformation to stable isotope ${ }^{40} \mathrm{Ca}:{ }^{40} \mathrm{~K}_{19} \rightarrow{ }^{40} \mathrm{Ca}_{20}+\mathrm{e}^{-}$. Emanated isotopes $\beta$-particles (electrons) ionize air atoms and molecules and then are grabbed by outer cover of air atoms and molecules and integrated to them. That forms negative ions.

As a second way of decomposition ${ }^{40} \mathrm{~K}$-ions experience K-grab (10.72\%) and transform to ${ }^{40} \mathrm{Ar}$. That core during transformation to stable state emits $\gamma$-quantum: ${ }^{40} \mathrm{~K}_{19}+\mathrm{e}^{-} \rightarrow{ }^{40} \mathrm{Ar}_{18}+h v$ and cause poor $\gamma$-emission.

The main physical characteristics of radioactive emissions, caused by ${ }^{40} \mathrm{~K}$ decomposition are presented in the Table 1.

Table 1 - The main characteristics of ${ }^{40} \mathrm{~K}$ ion emission

\begin{tabular}{|l|c|}
\hline \multicolumn{1}{|c|}{ Characteristic } & Value \\
\hline Half-life period, years & $1.248 \cdot 10^{9}$ \\
\hline $\begin{array}{l}\text { Concentration of isotopes in the natural } \\
\text { composition, \% }\end{array}$ & 0.0119 \\
\hline Energy of $\gamma$-emission, $\mathrm{MeV}$ & 1.505 \\
\hline Average emission energy of $\beta$-particles, $\mathrm{MeV}$ & 0.541 \\
\hline Threshold emission energy of $\beta$-particles, $\mathrm{MeV}$ & 1.322 \\
\hline
\end{tabular}


Ionization of mining and sylvinite speleoclimatic chambers is caused primarily by ionization emissions.

However, air ions and free electrons appear in the air when trigging energy of molecules and atoms due to influence of ionization emission create higher value than ionization potential.

It is well known that $\beta$-particles passing through matter experience elastic and inelastic interaction with nucleus and electrons of the surrounding environment. $\beta$-particle interaction with atomic electrons leads to energy transfer that causes eighter ionization or excitation of atoms. Both energy transmission types have common name "ionization losses" and are equally possible.

In the certain environment $\gamma$-emission loses its energy through the photoelectric effect or Compton-scattering with the main ionization influence on the air environment caused by secondary electrons.

\section{Research methods}

All studies were performed in a real special rooms lined by sylvinite blocks and panels in the absence of people (except the researcher).

The study of air ions concentration values was carried out using the integral ion spectrometer UT-8401, which allows registering air ions of positive and negative polarities in the mobility range from 0.00032 up to $2.0 \mathrm{~cm}^{2} \mathrm{~B}^{-1} \mathrm{sec}^{-1}$ and more.

\section{Concentration of air ions of different mobility groups in the air environment of premises, lined by special materials based on potassium salts}

Averaged values of air ion fractions with threshold mobility of $0.1,0.01$ and $0.00032 \mathrm{am}^{2} \mathrm{~B}^{-1} \mathrm{sec}^{-1}$ (light, moderate and heavy air ions groups respectively) under the considered limit with standard deviation are presented in the Table 2.

All measurements in the range of mobility more than $0.1 \mathrm{~cm}^{2} \mathrm{~B}^{-1} \mathrm{sec}^{-1}$ (light ions) are represented by air ions of positive polarity, which is characteristic of surface atmosphere due to the presence of an electric field of the Earth. The coefficient of unipolarity $Y=n_{+} / n_{-}$in the range of light air ions varies in the range of 1.08-1.57.

Volume concentration of moderate ions (mobility $0.01-0.10 \mathrm{~cm}^{2} \mathrm{~B}^{-1} \mathrm{sec}^{-1}$ ) of both polarities is much smaller than concentrations of both light and heavy ions, which is also characteristic for the composition of air ionic environment with relatively low ionization intensity.

In the field of heavy air ions (mobility of 0.00032-0.01000 $\mathrm{cm}^{2} \mathrm{~B}^{-1} \mathrm{sec}^{-1}$ ) following experimental fact indicated. The coefficient of unipolarity $\mathrm{Y}$ in the specified range changes its sign depending on time and measurement object. In some cases $(\sim 12 \%)$ concentration of heavy positive ions is more than the heavy negative. In other cases ( 88\%), vice versa, the concentration of heavy negative ions is more than heavy positive. It is noted that this difference is due to the magnitude of relative humidity.

Table 2 - Concentrations of air ions of different groups of mobility indoors with decorating materials based on potassium salt

\begin{tabular}{|l|c|c|c|c|c|c|}
\hline \multirow{2}{*}{ Object } & \multicolumn{5}{|c|}{ Volumetric concentration of air ions, $\mathrm{cm}^{-3}$} \\
\cline { 2 - 7 } & \multicolumn{2}{|c|}{$\begin{array}{c}\text { Mobility } \\
\text { more } 0.1 \mathrm{~cm}^{2} \mathrm{~B}^{-1} \mathrm{sec}^{-1}\end{array}$} & \multicolumn{2}{|c|}{$\begin{array}{c}\text { Mobility } \\
0.01-0.10 \mathrm{~cm}^{2} \mathrm{~B}^{-1} \mathrm{sec}^{-1}\end{array}$} & \multicolumn{2}{|c|}{$\begin{array}{c}\text { Mobility } \\
0.00032-0.01000 \mathrm{~cm}^{2} \mathrm{~B}^{-1} \mathrm{sec}^{-1}\end{array}$} \\
\cline { 2 - 7 } & $n_{+}$ & $n_{-}$ & $n_{+}$ & $n_{-}$ & $n_{+}$ & \multicolumn{2}{c}{$n_{-}$} \\
\hline $\begin{array}{l}\text { Premises lined by sylvinite blocks } \\
\text { of potassium salt }\end{array}$ & $2400 \pm 410$ & $2050 \pm 360$ & $230 \pm 70$ & $220 \pm 90$ & $1980 \pm 440$ & $2350 \pm 600$ \\
\hline $\begin{array}{l}\text { Premises fully lined with molded } \\
\text { potassium tiles molded }\end{array}$ & $1500 \pm 440$ & $1170 \pm 370$ & $260 \pm 100$ & $260 \pm 130$ & $2600 \pm 620$ & $3010 \pm 580$ \\
$\begin{array}{l}\text { Premises with decorative fragments } \\
\text { from the material based on potassium } \\
\text { salt (1.5 m on the active surface) }\end{array}$ & $1030 \pm 380$ & $1040 \pm 360$ & $230 \pm 80$ & $170 \pm 70$ & $1600 \pm 350$ & $1300 \pm 240$ \\
\hline
\end{tabular}




\section{The distribution of light air ions by the mobility in the premises lined with special materials based on potassium salts}

The study of spectrum in terms of mobility of positive and negative light ions in the range of 0.32 up to $2.2 \mathrm{~cm}^{2} \mathrm{~B}^{-1} \mathrm{sec}^{-1}$ was done. A typical spectral distribution of light air ions on mobility presented below.

Almost all light air ions are in mobility range of $1-2 \mathrm{~cm}^{2} \mathrm{~B}^{-1} \mathrm{sec}^{-1}$. It is noted that in the range of mobility larger than $2 \mathrm{~cm}^{2} \mathrm{~B}^{-1} \mathrm{sec}^{-1}$ unipolarity factor $Y$ is always less than 1 (an average value is $0.89 \pm 0.09$ ), while in the range of $1-2 \mathrm{~cm}^{2} \mathrm{~B}^{-1} \mathrm{sec}^{-1}$ unipolarity factor $\mathrm{Y}$ is always greater than 1 (an average is $2.74 \pm 1.38$ ). For the normal atmosphere characterized by unipolarity coefficient values in specified ranges of mobility of 0.68 and 1.33 respectively are common [23]. Mentioned experimental fact agrees with ionization processes in open air without any extraneous chemical impurities. The main negative air ions in the range of mobility of larger than $2 \mathrm{~cm}^{2} \mathrm{~B}^{-1} \mathrm{sec}^{-1}$ are ions $\mathrm{O}_{2}^{-}$ $\left(\mathrm{H}_{2} \mathrm{O}\right)_{m}$. Stable carrier of positive charge are presented much less in the range of mobility of 1-2 $\mathrm{cm}^{2} \mathrm{~B}^{-1} \mathrm{sec}^{-1}$ [23]. At the same time stable complexes $\mathrm{H}^{+}\left(\mathrm{H}_{2} \mathrm{O}\right)_{m}$ and $\mathrm{H}_{3} \mathrm{O}^{+}\left(\mathrm{H}_{2} \mathrm{O}\right)_{m}$, which are formed in large enough quantities and are the main positive light air ions, are within the range of mobility of $1-2 \mathrm{~cm}^{2} \mathrm{~B}^{-1} \mathrm{sec}^{-1}$.

\section{Discussion on the results}

Dependence of sign of $\mathrm{Y}$ unipolarity factor in the area of heavy ions (mobility of 0.00032$0.01000 \mathrm{~cm}^{2} \mathrm{~B}^{-1} \mathrm{sec}^{-1}$ ) versus time and measurement object (see table 2) may be explained by the specific properties of the aerosol particles of salt. As it is known, heavy air ions are generated by capturing of light ions by aerosol particles. In case of water cut increase, vaporization or condensation of water vapor then streams of air ions of different signs to hygroscopic aerosol particles will vary due to surface appearance of particles of layer with molecular water vapor. Such layers create local electric potential nearby split surface "water-air".

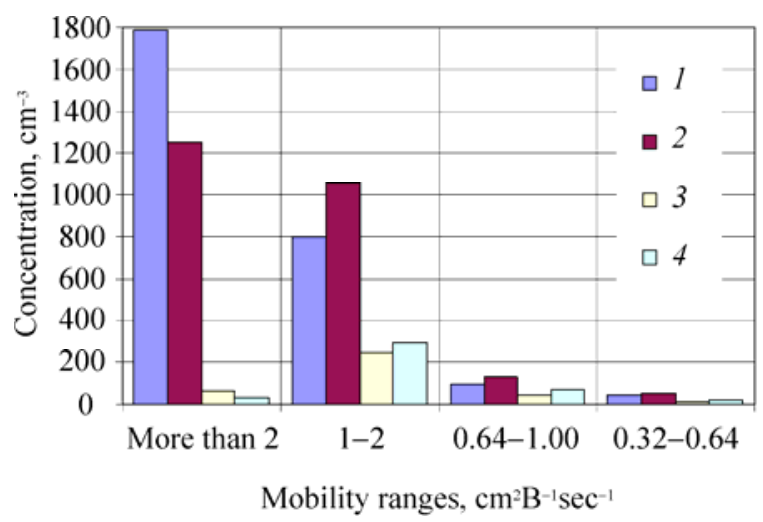

Fig. Typical spectral distribution of light positive (2, 4 ) and negative $(1,3)$ air ions in the air environment including decorative materials base on potassium salts $(1,2)$ and pure natural air $(3,4)$. Data 3 and 4 are taken from [23]

Rate of condensation processes and ability of aerosol to orient specifically adsorbed on the surface molecules of water vapor and dissociate it into the water determine sign and value of that potential. According to the model developed in [24], air ions of the same sign got the zone of potential influene are smoothly deposited on the drop (particle). Ions of opposite sign are "pushed" by potential, which reduces the flow of ions. According to experimental data [25] on the stage of flooding of salt aerosol particles the conditions of preferential adsorption of negative ions are formend. On the stage of condensation growth there are conditions for positive ions formations. The authors think selective deposition of air ions of different signs on aerosol particle determines sign of heavy air ions (see Table 2).

Moreover, it is know from [26], aerosol containing salts of sodium, potassium, magnesium has a clear hysteresis in the aggregate state of aerosol particles depending on relative humidity. Complete dissolution of salt particles takes place at $73-78 \%$ of relative humidity, but reverse crystallization occurs at a relative humidity of $30-40 \%$.

Mentioned above mechanisms explain the experimental fact that at a relative humidity of about $73 \%$ or more (critical relative humidity at which the majority of salt aerosol particles dissolve and are tiny droplets) concentration of heavy negative ions is always greater than the concentration of heavy positive ones. 
On the contrary, at a relative humidity of less than $73 \%$ the sign of unipolarity coefficient $Y$ of heavy ions can be either negative or positive. That depends on the nature of humidity of $73 \%$. If the relative humidity in the past exceeded the critical values equal to $73-78 \%$, then with a decrease of relative humidity to $30-40 \%$ aerosol particles remain in the liquid phase and light negative air ions are deposited. If the aerosol particles are not completely dissolved, i.e. relative humidity in the past did not exceed critical values of $73-78 \%$ then positive light air ions are deposited.

\section{Conclusions}

Special construction materials based on potassium salts influence on air ion and aerosol regime of premises are analyzed. Presented approach to determine unique properties of special construction and decorative materials allows explaining its applica- tion in scientific way, determining scenarios of use in air environment based on required parameters of aerosol composition and concentration in air environment in order to create air of highquality in the premises.

Obtained equivalence of parameters of air ion mobility distribution in the premises environment, lined by material with base of potassium salts, and in clean atmosphere air (see Fig. 1) prove the chemical nature of air ions in both environments is similar.

Volume concentration of air ions in the air into environment of premises, lined by special materials with base of potassium salts differ to natural air by an order of magnitude. That shows a possibility to use new state-of-the-art technologies of natural sylvinite application to create premises of medical and healthrecovering purposes.

\section{References}

1. Krueger A.P. Air ions and physiological function. The Journal of General Physiology, 1962, vol.45, pp.233-241.

2. Kröing P. Natural and artificially produced air ions - a biologically relevant climate factor? International Journal of Biometeorology, 1985, vol.29, no.3, pp.233-242. DOI: 10.1007/BF02189655.

3. Singh J. Health, comfort and productivity in the indoor environment. Indoor and Built Environment, 1996, vol.5, pp.22-33. DOI: 10.1177/ 1420326X9600500105.

4. Sekhar S.C., Ching C.S. Indoor air quality and thermal comfort studies of an under-floor air-conditioning system in the tropics. Energy and Buildings, 2002, vol.34, pp.431-444. DOI: 10.1016/S0378-7788(01)00128-1.

5. Franssona N., Västfjäll D., Skoog J. In search of the comfortable indoor environment: A comparison of the utility of objective and subjective indicators of indoor comfort. Building and Environment, 2007, vol.42, pp.1886-1890. DOI: 10.1016/j.buildenv.2006.02.021.
6. Tan R. The truth about air electricity \& health: A guide on the use of air ionization and other natural approaches for 21st century health issues. Singapure: Trafford Publishing, 2014. 168 p.

7. Liu L., Guo J., Sheng L. The effect of wire heating and configuration on ozone emission in negative ion generator. Journal of Electrostatics, 2000, vol.48, pp.81-91. DOI: 10.1016/S0304-3886(99)00049-2.

8. Rehbein N., Cooray V. $\mathrm{NO}_{x}$ production in spark and corona discharges. Journal of Electrostatics, 2001, vol.51-52, pp.333-339. DOI: 10.1016/S0304-3886(01)00115-2.

9. Sekimoto K., Takayama M. Influence of needle voltage on the formation of negative core ions using atmospheric pressure corona discharge in air. International Journal of Mass Spectrometry, 2007, vol.261, is.1, pp.38-44. DOI: 10.1016/j.ijms.2006.07.027.

10. Rashleigh R., Smith S. MS., Roberts N. A review of halotherapy for chronic obstructive pulmonary disease. International Journal of COPD, 2014, vol.9, pp.239-246. DOI: 10.2147/COPD.S57511. 
11. Krasnoshtein A.E. et al. Klimaticheskaia kamera [Climatic chamber]: patent 2012306 Ros. Federatsiia; no.4913631/14; zaiavlen 21.02.91; opublikovan 15.05.94.

12. Hedman J. et al. The effect of salt chamber treatment on bronchial hyperresponsiveness in asthmatics. Allergy, 2006, vol.61, pp.605-610. DOI: 10.1111/j.1398-9995.2006.01073.x.

13. Bariakh A.A. et al. Sposob izgotovleniia stroitel'nykh izdelii spetsial'nogo naznacheniia iz solianykh materialov [The method to manufacture construction products of salt materials for special purposes]: patent 2097359 Ros. Federatsiia; no.9510 1758/03; zaiavlen 06.02.95; opublikovan 27.11.97.

14. Simionca Iu. et al. Environment study in order to use potential therapeutic factors existing in the cavity of one salt mine for the achievement of some perspectives of speleotherapy development in Romania. Proceedings of the 14th International Congress of Speleology, 21-28 August, 2005. Kalamos, Hellas, 2005. Pp.421-425.

15. Enache L., Bunescu Iu. Microclimate and physical environment elements in some salt mines in Romania for speleotherapeutical use. The XIVth International Symposium of Speleoterapy: Abstracts. Turda, Romania, 2012, October 4-6. Cluj-Napoca: Casa Cărţii de Ştiinţă, 2012. Pp. 17-18.

16. Health effects of exposure to low levels of ionizing radiation: BEIR V. Committee on the Biological Effects of Ionizing Radiation, Board on Radiation Effects Research, Commission on Life Sciences, National Research Council. Washington D.C.: National Academy Press, 1996. 436 p.

17. Horowitz S. Salt cave therapy: rediscovering the benefits of an old preservative. Alternative and Complementary Therapies, 2010, vol.16, pp.158-162. DOI: 10.1089/act.2010.16302.

18. Kosiachenko G.E. Gigienicheskie osnovy kompleksnoi otsenki dobychi kaliinykh rud Belarusi i ratsional'nogo ispol'zovaniia speleosredy mestorozhdeniia [Hygienic bases of a complex estimation of ore potash mining in Belarus and rational use speleo environment of the field]: avtoreferat dissertatsii ... doktora meditsinskikh nauk. Minsk, 2004. 40 p.

19. Startsev V.A. et al. Radiologicheskoe issledovanie solianogo plasta $\mathrm{AB}$ kaliinogo rudnika [Radiological study of salt formation AB of potash mine]. Voprosy kompleksnogo osvoeniia nedr $i$ sovershenstvovaniia tekhnologii gornykh rabot na predpriiatiiakh Zapadnogo Urala: tezisy dokladov nauchnoi konferentsii Permskogo politekhnicheskogo instituta. Perm', 1983. Pp.21-22.

20. Tahir S.N.A., Alaamer A.S. Determination of natural radioactivity in rock salt and radiation doses due to its ingestion. Journal of Radiological Protection, 2008, vol.28, is.2, pp.233-236. DOI: 10.1088/0952-4746/28/2/N01.

21. Baloch M.A. et al. A study on natural radioactivity in Khewra Salt Mines, Pakistan. Journal of Radiation Research, 2012, vol.53, is.3, pp.411-421. DOI: 10.1269/jrr.11162.

22. Chonka Y. et al. Ionic composition of air in the underground department of Ukrainian allergic hospital. Abstracts of the XIVth International Symposium of Speleoterapy. Turda, 2012. Pp.14-15.

23. Hörrak U., Salm J., Tammet H. Statistical characterization of air ion mobility spectra at Tahkuse Observatory: Classification of air ions. Journal of Geophysical Research, Issues D: Atmospheres, 2000, vol. 105, pp.9291-9302. DOI: 10.1029/1999JD901197.

24. Borzilov V.A. Diffuzionnoe zariazhenie oblachnykh kapel' [Диффузионное заряжение облачных капель]: avtoreferat dissertatsii ... kandidata fiziko-matematicheskikh nauk. Obninsk, 1973. 29 p.

25. Savchenko A.V. Ionnaia zariadka pri kondensatsii i isparenii vodnogo aerozolia [Ionic charge in condensation and evaporation of water aerosol]: avtoreferat dissertatsii ... kandidata fizikomatematicheskikh nauk. Obninsk, 1981. 22 p.

26. Iunge Kh. Khimicheskii sostav i radioaktivnost' atmosfery [Chemical composition and radioactivity of atmosphere]. Moscow: Mir, 1965. 425 p. 


\section{Список литературы}

1. Krueger A.P. Air ions and physiological function // The Journal of General Physiology. 1962. - Vol. 45. - P. 233-241.

2. Kröing P. Natural and artificially produced air ions - a biologically relevant climate factor? // International Journal of Biometeorology. - 1985. - Vol. 29, № 3. - P. 233-242. DOI: 10.1007/ BF02189655.

3. Singh J. Health, comfort and productivity in the indoor environment // Indoor and Built Environment. - 1996. - Vol. 5. - P. 22-33. DOI: 10.1177/1420326X9600500105.

4. Sekhar S.C., Ching C.S. Indoor air quality and thermal comfort studies of an under-floor airconditioning system in the tropics // Energy and Buildings. - 2002. - Vol. 34 - P. 431-444. DOI: 10.1016/S0378-7788(01)00128-1.

5. Franssona N., Västfjäll D., Skoog J. In search of the comfortable indoor environment: A comparison of the utility of objective and subjective indicators of indoor comfort // Building and Environment. - 2007. - Vol. 42. - P. 18861890. DOI: 10.1016/j.buildenv.2006.02.021.

6. Tan R. The truth about air electricity \& health: A guide on the use of air ionization and other natural approaches for 21st century health issues. Singapure: Trafford Publishing, 2014. - 168 p.

7. Liu L., Guo J., Sheng L. The effect of wire heating and configuration on ozone emission in negative ion generator // Journal of Electrostatics. - 2000. - Vol. 48. - P. 81-91. DOI: 10.1016/S0304-3886(99)00049-2.

8. Rehbein N., Cooray V. $\mathrm{NO}_{x}$ production in spark and corona discharges // Journal of Electrostatics. - 2001. - Vol. 51-52. - P. 333-339. DOI: 10.1016/S0304-3886(01)00115-2.

9. Sekimoto K., Takayama M. Influence of needle voltage on the formation of negative core ions using atmospheric pressure corona discharge in air // International Journal of Mass Spectrometry. 2007. - Vol. 261, is. 1. - P. 38-44. DOI: 10.1016/j.ijms.2006.07.027.

10. Rashleigh R., Smith S. MS., Roberts N. A review of halotherapy for chronic obstructive pulmonary disease // International Journal of COPD. - 2014. - Vol. 9. - P. 239-246. DOI: 10.2147/COPD.S57511.

11. Климатическая камера: пат. 2012306 Рос. Федерация / А.Е. Красноштейн [и др.]. № 4913631/14; заявл. 21.02.91; опубл. 15.05.94.

12. The effect of salt chamber treatment on bronchial hyperresponsiveness in asthmatics / J. Hedman [et al.] // Allergy. - 2006. - Vol. 61. P. 605-610. DOI: 10.1111/j.1398-9995.2006.01073.x.

13. Способ изготовления строительных изделий специального назначения из соляных материалов: пат. 2097359 Рос. Федерация / А.А. Барях [и др.]. - № 95101758/03; заявл. 06.02.95; опубл. 27.11.97.

14. Environment study in order to use potential therapeutic factors existing in the cavity of one salt mine for the achievement of some perspectives of speleotherapy development in Romania / Iu. Simionca [et al.] // Proceedings of the 14th International Congress of Speleology, 21-28 August, 2005, Kalamos, Hellas. - P. 421-425.

15. Enache L., Bunescu Iu. Microclimate and physical environment elements in some salt mines in Romania for speleotherapeutical use // The XIVth International Symposium of Speleoterapy: Abstracts. Turda, Romania, 2012, October 4-6. - Cluj-Napoca: Casa Cărţii de Ştiinţă, 2012. - P. 17-18.

16. Health effects of exposure to low levels of ionizing radiation: BEIR V / Committee on the Biological Effects of Ionizing Radiation, Board on Radiation Effects Research, Commission on Life Sciences, National Research Council. - Washington D.C.: National Academy Press, 1996. - 436 p.

17. Horowitz S. Salt cave therapy: rediscovering the benefits of an old preservative // Alternative and Complementary Therapies. - 2010. - Vol. 16. P. 158-162. DOI: 10.1089/act.2010.16302.

18. Косяченко Г.Е. Гигиенические основы комплексной оценки добычи калийных руд Беларуси и рационального использования спелеосреды месторождения: автореф. дис. ... д-ра мед. наук. - Минск, 2004. - 40 с. 
19. Радиологическое исследование соляного пласта АБ калийного рудника / В.А. Старцев [и др.] // Вопросы комплексного освоения недр и совершенствования технологии горных работ на предприятиях Западного Урала: тез. докл. науч. конф. Пермского политехн. ин-та. Пермь, 1983. - С. 21-22.

20. Tahir S.N.A., Alaamer A.S. Determination of natural radioactivity in rock salt and radiation doses due to its ingestion // Journal of Radiological Protection. - 2008. - Vol. 28, is. 2. - P. 233-236. DOI: $10.1088 / 0952-4746 / 28 / 2 /$ N01.

21. A study on natural radioactivity in Khewra Salt Mines, Pakistan / M.A. Baloch [et al.] // Journal of Radiation Research. 2012. - Vol. 53, is. 3. - P. 411-421. DOI: $10.1269 /$ jrr.11162.

22. Ionic composition of air in the underground department of Ukrainian allergic hospital /
Y. Chonka [et al.] // Abstracts of the XIVth International Symposium of Speleoterapy. Turda, 2012. - P. 14-15.

23. Hörrak U., Salm J., Tammet H. Statistical characterization of air ion mobility spectra at Tahkuse Observatory: Classification of air ions // Journal of Geophysical Research. Issues D: Atmospheres. - 2000. - Vol. 105. - P. 9291-9302. DOI: 10.1029/1999JD901197.

24. Борзилов В.А. Диффузионное заряжение облачных капель: автореф. дис. ... канд. физ.мат. наук. - Обнинск, 1973. - 29 с.

25. Савченко А.В. Ионная зарядка при конденсации и испарении водного аэрозоля: автореф. дис. ... канд. физ.-мат. наук. Обнинск, 1981. - 22 с.

26. Юнге X. Химический состав и радиоактивность атмосферы. - М.: Мир, 1965. - 425 c.

Please cite this article in English as:

Chernyi K.A., Fainburg G.Z. Use of sylvinite dedicated to Verkhnekamskoe field of potash and magnesium to increase quality and ionization of air environment. Bulletin of PNRPU. Geology. Oil \& Gas Engineering \& Mining, 2016, vol.15, no 19, pp.185-192. DOI: 10.15593/2224-9923/2016.19.9

Просьба ссылаться на эту статью в русскоязычных источниках следующим образом:

Черный К.А., Файнбург Г.З. Использование сильвинита Верхнекамского месторождения калийно-магниевых солей для повышения качества воздушной среды и уровня ее ионизации // Вестник Пермского национального исследовательского политехнического университета. Геология. Нефтегазовое и горное дело. - 2016. - Т.15, №19. - C.185-192. DOI: 10.15593/2224-9923/2016.19.9 